\title{
PENDETEKSIAN KECURANGAN LAPORAN KEUANGAN DENGAN ANALISIS FRAUD PENTAGON
}

\author{
Utami Puji Lestari ${ }^{1}$ \\ Fitri Dwi Jayanti² \\ ${ }^{1}$ Fakultas Ekonomika dan Bisnis Universitas Selamat Sri Kendal \\ Email : utamipujilestarizufar@gmail.com \\ ${ }^{2}$ Fakultas Ekonomi, Hukum dan Humaniora Universitas Ngudi Waluyo Semarang \\ Email : fitridj82@gmail.com
}

\begin{abstract}
ABSTRAK
Tujuan penelitian ini adalah untuk mengetahui pengaruh stabilitas keuangan, tekanan eksternal, target keuangan, kesempatan, rasionalisasi, kompetensi dan arogansi terhadap pendeteksian kecurangan laporan keuangan. Fraud Pentagon Theory mempunyai peranan penting dalam pengungkapan kecurangan laporan keuangan. Teknik pengambilan sampel menggunakan purposive sampling, populasi pada penelitian ini adalah Seluruh perusahaan manufaktur yang terdaftar di Bursa Efek Indonesia dari tahun 2015 sampai tahun 2018. Jumlah sampel pada penelitian ini ialah 72 perusahaan. Alat analisis menggunakan analisis regresi linear berganda. Hasil penelitian menunjukkan bahwa stabilitas keuangan, target keuangan, kesempatan, rasionalisasi, kompetensi dan arogansi tidak berpengaruh terhadap pendeteksan kecurangan laporan keuangan dan tekanan eksternal berpengaruh terhadap pendeteksian kecurangan laporan keuangan.
\end{abstract}

Kata Kunci: stabilitas keuangan, tekanan eksternal, target keuangan, kesempatan, rasionalisasi, kompetensi, arogansi, kecurangan laporan keuangan

\section{PENDAHULUAN}

Informasi yang dihimpun oleh Indonesia Corruption Watch, kasus korupsi yang yang terjadi di Indonesia selama tahun 2019 telah menyebabkan kerugian keuangan negara sebesar Rp 8,4 triliun (nasional.kompas.com). Korupsi dibidang keuangan terjadi dengan cara memanipulasi laporan keuangan. Laporan keuangan merupakan informasi hasil dari kinerja perusahaan. Laporan keuangan memiliki berbagai jenis informasi keuangan yang dibutuhkan oleh berbagai pihak. Stakeholder perlu diyakinkan bahwasannya laporan keuangan bebas dari kecurangan atau penipuan, akan tetapi meskipun laporan tersebut telah diaudit oleh akuntan publik dan penyusunan laporan keuangan tersebut sesuai dengan pernyataan standar akuntansi keuangan yang berlaku, tidak dapat menjamin bahwasanya laporan keuangan tersebut bebas dari kecurangan (Rusmana dan Hendra, 2019).

Perusahaan tumbuh dan berkembang mengalami pasang surut. Pihak manajemen tentunya akan mempertahankan kelangsungan hidup perusahaan dengan adanya investasi dari pihak luar. Untuk meyakinkan investor, pihak manajemen perusahaan akan melakukan berbagai cara, salah satunya dengan memanipulasi laporan keuangan agar investor tertarik untuk melakukan investasi. Akan tetapi, prosedur dan ketentuan manipulasi laporan keuangan sering diabaikan oleh pihak manajemen, sehingga laporan keuangan perlu diaudit oleh auditor internal dan eksternal. Sehingga laporan keuangan yang disajikan kepada publik / pengguna sudah sesuai dengan standar akuntansi keuangan yakni relevansi, handal, kelengkapan, ketetapan waktu, dimengerti, verifiability dan dapat daikses. Meskipun data laporan keuangan sudah diaudit oleh auditor, belum tentu laporan keuangan tersebut mengambarkan kinerja keuangan perusahaan yang sesuangguhnya.

Kantor Akuntansi Publik mempunyai tugas dan wewenang untuk mengaudit laporan keuangan yang telah dibuat oleh pihak manajemen perusahaan. Sehingga laporan keuangan yang telah dibuat oleh pihak manajemen dapat dipertanggungjawabkan. Auditor mengaudit laporan keuangan, hal ini dikarenakan ada kemungkinan, laporan keuangan tersebut mengandung kesalahan baik yang disengaja maupun tidak disengaja. Karena itu laporan keuangan yang belum diaudit kurang dipercaya kewajarannya oleh pihakpihak yang berkepentingan terhadap laporan keuangan tersebut. Jika laporan keuangan sudah diaudit dan mendapat opini wajar tanpa pengecualian, berarti pengguna laporan keuangan bisa yakin bahwa laporan 
keuangan tersebut bebas dari salah saji material dan disajikan sesuai dengan standar akuntansi yang berlaku umum di Indonesia (Agoes, 2018:13). Akan tetapi meskipun laporan keuangan sudah diaudit oleh KAP, belum tentu laporan keuangan tersebut dapat dipercaya. Contohnya kasus-kasus yang pernah terjadi di perusahaan BUMN (Badan Usaha Milik Negara) yang pada akhir tahun ini menjadi tranding topic.

Kasus kecurangan laporan keuangan akhir-akhir ini marak terjadi di perusahaan manufaktur. Sebut saja Toshiba, PT Hanson Internasional, dan PT Tiga Pilar Sejahtera Food Tbk telah terbukti melakukan kecuranga laporan keuangan. Kasus perusahaan manufaktur ini terjadi selama 3 tahun berturut-turut yakni tahun 2015 untuk kasus Tosiba, tahun 2016 kasus PT Hanson International dan tahun 2017 kasus PT Tiga Pilar Sejahtera Food Tbk (AISA).

Pada bulan Mei 2015, Toshiba mengejutkan seluruh dunia saat menyatakan bahwa perusahaannya tengah melakukan investigasi atas skandal akuntansi internal dan harus merevisi perhitungan laba dalam 3 tahun terakhir. Pengumuman tersebut sangat tidak disangka karena Toshiba telah menjadi lambang perusahaan Jepang yang sangat kuat. Setelah diinvestigasi secara menyeluruh, diketahuilah bahwa Toshiba telah kesulitan mencapai target keuntungan bisnis sejak tahun 2008 di mana pada saat tengah terjadi krisis global. Krisis tersebut juga melanda usaha Toshiba hingga akhirnya Toshiba melakukan suatu kebohongan melalui accounting fraud senilai 1.22 milyar dolar Amerika.Tindakan ini dilakukan dengan berbagai upaya sehingga menghasilkan laba yang tidak sesuai dengan realita.

Dalam catatan Otoritas Jasa Keuangan (OJK), PT Hanson International pernah terbukti melakukan manipulasi penyajian laporan keuangan tahunan (LKT) untuk tahun 2016. OJK pun menjatuhkan sanksi, baik untuk perusahaan maupun direktur utamanya, Benny Tjokro. Dalam pemeriksaan yang dilakukan OJK, ditemukan manipulasi dalam penyajian akuntansi terkait penjualan kavling siap bangun (Kasiba) dengan nilai gross Rp 732 miliar, sehingga membuat pendapatan perusahaan naik tajam. Dalam jual beli tersebut, Hanson International melakukan pelanggaran Standar Akuntansi Keuangan 44 tentang Akuntansi Aktivitas Real Estat (PSAK 44). Karena rekayasa LKT tersebut, OJK menjatuhkan sanksi PT Hanson International Tbk dikenai denda sebesar Rp 500 juta dan perintah untuk melakukan perbaikan dan penyajian kembali atas LKT 2016. Sementara CEO PT Hanson International Benny Tjokro dijatuhi sanksi denda Rp 5 miliar. Direksi lainnya, Adnan Tabrani juga dikenai sanksi denda Rp 100 juta. Kemudian pada Sherly Jokom, auditor dari Kantor Akuntan Publik (KAP) Purwantono, Sungkoro dan Surja, member dari Ernst and Young Global Limited (EY), dengan hukuman pembekuan Surat Tanda Terdaftar (STTD) selama satu tahun.

Kisruh soal kasus PT Tiga Pilar Sejahtera Food Tbk (AISA) kembali menyeruak belakangan ini. Lembaga akuntan publik Ernst \& Young (EY) sudah mengeluarkan audit soal dugaan pelanggaran yang dilakukan oleh manajemen lama AISA. Terdapat beberapa poin penting yang dibeberkan oleh EY dalam keterbukaan informasi yaitu terkait pembanding antara data internal dengan Laporan Keuangan 2017 yang telah diaudit. Poin-poin itu di antaranya yang pertama, terdapat dugaan overstatement sebesar Rp 4 triliun pada akun piutang usaha, persediaan, dan aset tetap Grup AISA dan sebesar Rp 662 miliar pada penjualan serta Rp 329 miliar pada EBITDA Entitas Food. Yang kedua, terdapat dugaan aliran dana sebesar Rp 1,78 triliun dengan berbagai skema dari Grup AISA kepada pihak-pihak yang diduga terafiliasi dengan manajemen lama antara lain dengan menggunakan pencairan pinjaman AISA dari beberapa bank, pencairan deposito berjangka, transfer dana di rekening Bank, dan pembiayaan beban Pihak Terafiliasi oleh Grup AISA.Yang ketiga terkait hubungan dan transaksi dengan Pihak Terafiliasi, tidak ditemukan adanya pengungkapan (disclosure) secara memadai kepada para pemangku kepentingan (stakeholders) yang relevan.

Fraud yang terjadi pada perusahaan manufaktur tersebut, dilakukan secara sengaja oleh pihak manajemen perusahaan. Fraud yang dilakukan adalah dengan memanipulasi laporan keuangan agar sesuai dengan keinginan manajemen sehingga dapat mengungtungkan perusahaan. Akan tetapi hal tersebut merugikan pihak pengguna terutama pihak eksternal. Agar kasus kecurangan tidak terulang kembali, fraud pentagon theory mempunyai peranan penting dalam pengungkapan kecurangan laporan keuangan. Teori Fraud Triangel dikembangkan menjadi fraud pentagon theory. Danuta (2017) memproyeksikan indikator dari pentagon theory adalah arogansi, kompetensi, kesempatan, tekanan dan rasionalisasi. Hasil analisis menunjukan e-procurement dapat mengurangi timbulnya arogansi dan kompetensi melalui transparansi yang diperoleh setelah menggunakan e-procuremen. Bawekes, Aaron dan Sylvia (2018) menyatakan 
Fraudulent financial reporting selama berjalannya waktu semakin mengalami peningkatan, hal ini tidak bisa dianggap remeh oleh semua pihak. Banyaknya kasus kejahatan ekonomi yang terjadi dalam dunia bisnis, mengharuskan para auditor untuk mengetahui faktor-faktor apa saja yang dapat mendeteksi terjadinya fraud pada perusahaan. Dengan berkembangnya zaman, ilmu pengetahuan mengenai fraud juga bisa dilihat dari penelitian-penelitian terdahulu yang memberikan gambaran mengenai praktik kecurangan pelaporan keuangan. Hasil penelitian yang dilakukan oleh Rusmana dan Hendra (2019) dengan identifikasi kecurangan laporan keuangan dengan fraud pentagon menunjukkan hasil bahwa variabel tekanan eksternal yang diukur dengan leverage berpengaruh terhadap kecurangan laporan keuangan. Hasil penelitian Septriani dan Desi (2018) juga menyatakan bahwa tekanan eksternal dan stabilitas keuangan berpengaruh terhadap kecurangan laporan keuangan. Hasil penelitian Hidayah dan Galih (2019) juga menyatakan bahwa variabel target keuangan dan pergantian auditor dapat mendeteksi adanya kecurangan laporan keuangan.

\section{KAJIAN PUSTAKA DAN PENGEMBANGAN HIPOTESIS}

Teori terbaru yang mengungkapkan lebih banyak tentang faktor yang dapat mendeteksi penipuan adalah teori penipuan Pentagon. Teori ini terungkap dalam 2010 oleh Jonathan Marks, salah satu mitra yang bertanggung jawab atas praktek penipuan dan etika di Crowe Horwarth LLP, yang merupakan salah satu perusahaan akuntansi publik terbesar dan konsultan di Amerika Serikat. Ini teori penipuan Pentagon adalah pengembangan dari teori segitiga penipuan yang sebelumnya diusulkan oleh Cressey pada 1953.

Dalam teori ini, dua unsur penipuan ditambahkan, yaitu kompetensi dan arogansi. Kompetensi yang diungkapkan dalam teori penipuan di Pentagon ini memiliki arti yang hampir sama dengan kemampuan yang dijelaskan oleh Wolfe dan Hermanson (2004). Kompetensi adalah kemampuan seseorang untuk melakukan penipuan. Sementara kesombongan adalah karakter seseorang yang merasa bahwa ia memiliki kekuasaan atas segala sesuatu di perusahaan, dengan mengabaikan kontrol internal yang ada di perusahaannya, mengembangkan strategi penipuan, dan mengawasi situasi sosial yang akan membuat keuntungan pribadi (Crowe, 2011).

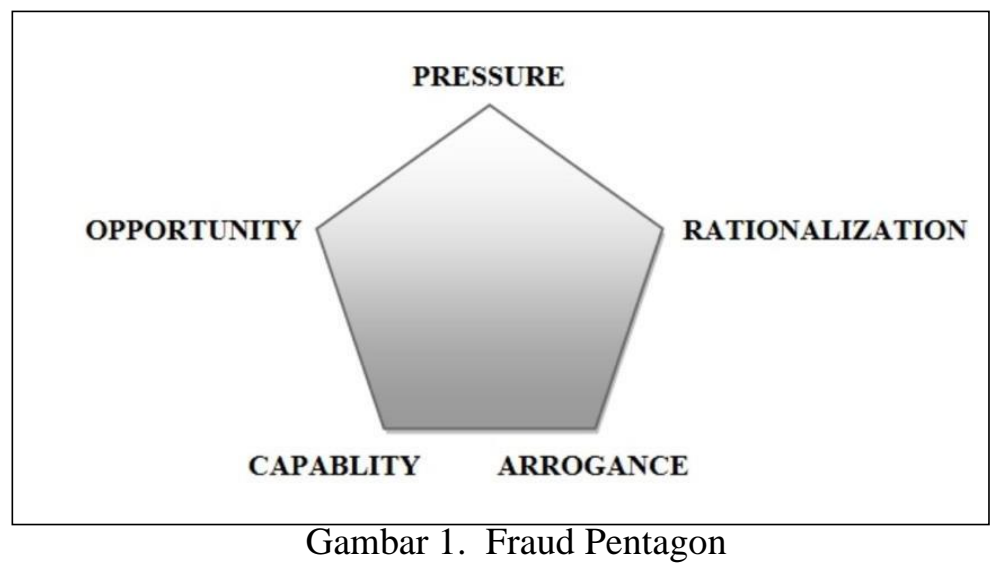

Marks (2012) menjelaskan masing-masing elemen tersebut sebagai berikut: (1) tekanan (pressure) didefinisikan sebagai adanya motif untuk melakukan dan menyembunyikan kecurangan, (2) kesempatan (opportunity) merupakan adanya kesempatan untuk melakukan kecurangan yang diakibatkan oleh lemahnya pengendalian, (3) rasionalisasi (rasionalization) merupakan pembenaran atas kecurangan yang sedang direncanakan atau kecurangan yang telah terjadi, (4) kompetensi atau keterampilan (capability) merupakan kemampuan seseorang untuk mengesampingkan atau mengabaikan pengendalian internal, mengembangkan suatu strategi penyembunyian yang canggih, dan mengendalikan situasi sosial untuk keuntungannya dan/atau dengan menjualnya kepada orang lain, dan (5) arogansi (arrogance) merupakan sikap superioritas seseorang yang berkombinasi dengan hak atau keserakahan dan suatu keyakinan bahwa pengendalian internal tidak berlaku baginya. Masing-masing elemen atau kombinasi dari beberapa elemen dapat mendorong seseorang melakukan kecurangan atau penipuan. Namun, elemen kompetensi dan arogansi memiliki peran utama dalam mendorong terjadinya kecurangan atau penipuan. 
Keinginan bagi manajer agar perusahaan terlihat baik kinerjanya oleh berbagai pihak sering mengakibatkan manajer memanipulasi bagianbagian tertentu pada laporan keuangan, sehingga pada akhirnya menyajikan informasi yang tidak semestinya dan tentunya akan merugikan berbagai kepentingan. Kecurangan-kecurangan yang dilakukan perusahaan untuk memanipulasi laporan keuangan sering disebut dengan fraud, dan praktik kecurangan terhadap pelaporan keuangan disebut fraudulent financial reporting (Sasongko dan Sangrah, 2019).

Rusmana dan Hendra (2019) menyatakan bahwa stabilitas keuangan, tekanan eksternal, target keuangan, pengawasan yang tidak efektif, pergantian auditor, pergantian direktur, dan gambar CEO dapat digunakan untuk mendeteksi kecurangan laporan keuangan atau dengan makna lain bahwa variabelvariabel tersebut memiliki pengaruh terhadap kecurangan laporan keuangan. Adanya kecurangan laporan keuangan akan menurunkan kualitas dan integritas informasi keuangan yang disajikan serta mempengaruhi para pihak yang memiliki kepentingan atas informasi yang disampaikan seperti investor dan kreditor. Selain investor dan kreditor, Auditor juga merupakan pihak yang paling dirugikan akibat adanya kecurangan laporan keuangan. Kerugian yang di alami oleh auditor adalah kejatuhan reputasi yang menyebabkan ketidakpercayaan. Oleh sebab itu, auditor harus memiliki mekanisme yang tepat untuk mendeteksi adanya kecurangan laporan keuangan.

Septriani dan Desi (2018) juga mengungkapkan bahwa tujuan untuk menganalisis teori fraud pentagon dalam mendeteksi kecurangan laporan keuangan (fraudulent financial statement). Elemenelemen teori fraud pentagon yaitu, tekanan (pressure), peluang (opportunity), rasionalisasi (rationalization), kompetensi (competence) dan arogansi (arrogance). fraudulent financial reporting adalah kekeliruan yang disengaja dari kondisi keuangan suatu perusahaan yang dilakukan melalui perbuatan salah saji dan kelalaian dari jumlah atau pengungkapan dalam laporan keuangan untuk menipu pengguna laporan keuangan. Fraudulent financial reporting meliputi manipulasi, pemalsuan, atau alteration catatan akuntansi atau dokumen pendukung dari laporan keuangan yang disusun tidak menyajikan kebenaran atau dengan sengaja menghilangkan kejadian, transaksi, dan informasi penting dari laporan keuangan dan dengan sengaja menerapkan prinsip akuntansi yang salah.

Danuta (2017) melakukan penelitian Crowe's Fraud Pentagon Theory dalam Pencegahan Fraud pada Proses Pengadaan melalui E-eprocurement dengan indikator Argansi, Kompetensi, Kesempatan, Tekanan dan Rasionalisasi. Arogansi diidentifikasikan sebagai sikap superioritas dan merasa berhak atau keserakahan sebagai bagian dari seseorang yang percaya bahwa pengendalian internal tidak berlaku terhadap pribadinya. Kompetensi adalah kemampuan karyawan untuk mengesampingkan pengendalian internal, dengan mengambangkan strategi penyimpangan yang canggih dan untuk mengendalikan situasi sosial demi keuntungannya dengan cara menjualnya kepada orang lain. Kesempatan merupakan pengendalian yang lemah menyediakan kesempatan bagi seseorang untuk melakukan fraud. Tekanan terdapat motivasi untuk melakukan fraud. Rasionalisasi merupakan pembenaran atas pencurian atau fraud yang sudah terjadi.

\section{H1. Pengaruh Stabilitas Keuangan terhadap Pendeteksian Kecurangan Laporan Keuangan}

Sifat industri adalah situasi yang ideal dan kondisi perusahaan di lingkungan industri. Sifat industri dapat menciptakan kesenjangan bagi perusahaan untuk melakukan penipuan laporan keuangan. Kerentanan muncul karena peraturan industri yang mengharuskan perusahaan untuk memiliki kemampuan pembenaran subjektif dalam menghitung perkiraan pada akun tertentu. Piutang dan inventori memerlukan penilaian subjektif dan harus diawasi karena mereka sering menjadi objek manipulasi laporan keuangan. Manajemen akan mencoba berbagai cara sehingga aset terlihat tinggi, salah satu jalan pintas memanipulasi nilai aset dalam laporan keuangan. Dalam sebuah perusahaan perbankan, piutang memiliki nilai yang signifikan dari total aset.

Ha1: Stabilitas keuangan berpengaruh terhadap pendeteksian kecurangan laporan keuangan

\section{H2. Pengaruh Tekanan Eksternal terhadap Pendeteksian Kecurangan Laporan Keuangan}

Tekanan eksternal adalah kondisi di mana suatu entitas mendapat tekanan dari pihak luar. Salah satu contoh tekanan eksternal yang terjadi di perusahaan adalah ketika sebuah perusahaan mencari sumber pendanaan untuk meningkatkan kinerja operasional dan non-operasional melalui pinjaman kepada kreditor. 
Tapi apa yang ditakuti bagi setiap perusahaan adalah kesulitan memenuhi persyaratan kreditor dan melunasi utang ketika mereka jatuh tempo. Salah satu kondisi yang diberikan oleh kreditor adalah bahwa perusahaan harus menampilkan kinerja keuangan dan diyakini dapat membayar kembali pinjaman tersebut. Ini adalah apa yang mendorong manajer untuk memanipulasi (Skousen 2009).

Ha2: Tekanan eksternal berpengaruh terhadap pendeteksian kecurangan laporan keuangan

\section{H3. Pengaruh Target Keuangan terhadap Pendeteksian Kecurangan Laporan Keuangan}

Target keuangan adalah pencapaian moneter yang harus dipenuhi oleh seorang manajer dalam satu periode. Tuntutan ini dapat menyebabkan tekanan pada manajer. Hal ini dapat membuat celah bagi manajer untuk memanipulasi laporan keuangan sehingga kinerja mereka terlihat sesuai dengan target yang ditetapkan. Dalam studi Skousen et al (2009), target keuangan diukur menggunakan Return on Aktiva (ROA). Return on Aktiva (ROA) digunakan untuk menunjukkan seberapa banyak tingkat pengembalian aset terhadap keuntungan yang dihasilkan oleh perusahaan, sehingga perusahaan menggunakan ROA sebagai alat ukur untuk menilai kinerja manajer perusahaan. Selain itu, ROA juga dapat digunakan untuk mengetahui seberapa efisien aset bekerja. Semakin tinggi target ROA di sebuah perusahaan, semakin tinggi potensi laporan keuangan palsu yang dilakukan melalui manajemen penghasilan. Ketika target ROA tinggi, manajemen akan berusaha untuk mencapai target ini. Ketika realisasi ROA menunjukkan nilai di bawah target itu akan mendorong manajemen untuk meningkatkan keuntungan dalam laporan keuangan.

Ha3: Target keuangan berpengaruh terhadap pendeteksian kecurangan laporan keuangan

\section{H4. Pengaruh Kesempatan terhadap Pendeteksian Kecurangan Laporan Keuangan}

Perusahaan yang memiliki sistem monitoring yang baik dapat mengurangi potensi praktek penipuan laporan keuangan yang dilakukan oleh agen. Untuk mengawasi kinerja manajemen secara langsung, investor mempercayakan kepada Dewan Komisaris. Dewan Komisaris berperan untuk mengawasi manajemen dalam membuat keputusan bisnis, memastikan realisasi strategi perusahaan, dan memastikan realisasi akuntabilitas keuangan di perusahaan. Dewan Komisaris diklasifikasikan dalam dua jenis yaitu Dewan Komisaris dan Dewan Komisaris Independen. Delegasi Dewan Komisaris adalah Dewan Komisaris yang memiliki hubungan dekat (berafiliasi) dengan investor dan/atau Direktur di perusahaan. Sedangkan Dewan Komisaris Independen adalah Dewan Komisaris yang dipilih berdasarkan keputusan Rapat Umum Pemegang Saham (RUPS), dengan syarat tidak berafiliasi dengan pihak manapun, terutama investor, Direktur, atau Komisaris lainnya. Hal ini dimaksudkan untuk menjaga profesionalisme dan kemandirian Dewan Komisaris dalam memantau kinerja manajemen.

Ha4: Kesempatan berpengaruh terhadap pendeteksian kecurangan laporan keuangan

\section{H5. Pengaruh Rasionalisasi terhadap Pendeteksian Kecurangan Laporan Keuangan}

Rasionalisasi adalah sikap dan perilaku yang timbul dari pikiran seseorang yang membenarkan tindak pidana, kecurangan dan penipuan yang dilakukannya. Rasionalisasi dapat menyebabkan seseorang yang awalnya tidak memiliki niat untuk melakukan penipuan, berubah menjadi melakukan penipuan tersebut dan dianggap normal. Rasionalisasi akan terus terjadi ketika ada kegagalan audit berulang. Audit kegagalan dapat terjadi ketika ada perubahan Auditor di perusahaan (Skousen et al 2008). Alasannya, auditor baru masih belum memahami keseluruhan kondisi perusahaan. Jadi ada penipuan yang dilakukan oleh manajemen yang tidak terdeteksi oleh auditor eksternal. Oleh karena itu, manajemen akan terus melakukan penipuan pelaporan keuangan dan menganggapnya wajar karena penipuan bukan merupakan temuan auditor eksternal.

Ha5: Rasionalisasi berpengaruh terhadap pendeteksian kecurangan laporan keuangan

\section{H6. Pengaruh Kompetensi terhadap Pendeteksian Kecurangan Laporan Keuangan}

Perubahan Direksi (perubahan Direktur) adalah pendelegasian tugas dan wewenang dari Dewan Direksi lama kepada Direksi baru dengan tujuan untuk meningkatkan kinerja Direksi sebelumnya. Hal ini menunjukkan bahwa kinerja Direktur lama tidak baik/dianggap tidak memuaskan dan dapat mengindikasikan penipuan dalam laporan keuangan. Perubahan Direktur dikatakan berhasil ketika Direktur baru dapat mencegah dan mengurangi penipuan dalam laporan keuangan. Sebaliknya, jika Direktur baru tidak dapat mencegah dan mengurangi penipuan laporan keuangan di perusahaan, perubahan Direktur 
dinyatakan kegagalan. Bahkan lebih buruk lagi, jika Direktur baru menggunakan kemampuannya untuk melakukan penipuan.

Ha6: Kompetensi berpengaruh terhadap pendeteksian kecurangan laporan keuangan

\section{H7. Pengaruh Arogansi terhadap Pendeteksian Kecurangan Laporan Keuangan}

Kesombongan adalah karakter dari seseorang yang merasa bahwa ia memiliki kekuasaan atas segala sesuatu di perusahaan. Karakter ini dapat menyebabkan seseorang untuk berani melakukan tindakan penipuan karena ia memiliki asumsi bahwa pengendalian internal dan peraturan yang diberlakukan di perusahaan tidak akan berlaku baginya. Arrogance dapat diukur dengan mengidentifikasi jumlah CEO gambar. Jumlah gambar CEO adalah jumlah penggambaran seorang CEO di perusahaan dengan menampilkan profil foto dan/atau informasi lain tentang track record CEO yang ditampilkan berulang kali dalam laporan tahunan perusahaan (Crowe, 2011).

Ha7: Arogansi berpengaruh terhadap pendeteksian kecurangan laporan keuangan

\section{METODE PENELITIAN}

Jenis penelitian yang digunakan adalah penelitian kuantitatif. Sistematis, terencana dan terukur adalah ciri khas dari penelitian kuantitatif. Data sekunder adalah sumber data yang digunakan, peneliti memperoleh data berupa laporan keuangan perusahaan manufaktur dari www.idx.go.id. Seluruh perusahaan manufaktur yang terdaftar di Bursa Efek Indonesia dari tahun 2015 sampai tahun 2018 adalah populasi pada penelitian ini. Penelitian ini menggunakan perusahaan manufaktur dikarenakan fenomena yang terjadi dilapangan menunjukkan bahwa tindakan kecurangan laporan keuangan dilakukan oleh perusahaan manufaktur dan terjadi pada kurun waktu tahun 2015 sampai tahun 2018. Purposive sampling adalah teknik pengambilan sampel yang dipilih dan digunakan oleh peneliti, dengan periode penelitian adalah 4 tahun, memperoleh 18 perusahaan. Total sampel yang digunakan adalah 72 observasi yang berasal sari (18 perusahaan $\mathrm{x} 4$ tahun). Variabel terikat dan variabel bebas adalah variabel yang ada pada penelitian ini.

\begin{tabular}{|c|c|c|c|}
\hline No & Nama Variabel & Indikator & Skala \\
\hline 1 & $\begin{array}{l}\text { Manajemen Laba } \\
(\mathrm{ML})\end{array}$ & $\mathrm{TAC}_{\mathrm{it}}=$ Nlit $-\mathrm{CFO}_{\mathrm{it}}$ & Rasio \\
\hline 2 & $\begin{array}{l}\text { Stabilitas Keuangan } \\
\text { (ACHANGE) }\end{array}$ & Perubahan Total Aset $=\frac{\text { Total Aset } \mathrm{t}-\text { total aset } \mathrm{t}-1}{\text { total aset } \mathrm{t}} \times 100 \%$ & Rasio \\
\hline 3 & $\begin{array}{l}\text { Tekanan Ekternal } \\
\text { (LEV) }\end{array}$ & Leverage $(D A R)=\frac{\text { total utang }}{\text { total aset }} X 100 \%$ & Rasio \\
\hline 4 & $\begin{array}{l}\text { Target Keuangan } \\
\text { (ROA) }\end{array}$ & $R O A=\frac{\text { laba sebelum pajak }}{\text { total aset }} X 100 \%$ & Rasio \\
\hline 5 & $\begin{array}{l}\text { Kesempatan } \\
\text { (BDOUT) }\end{array}$ & Kesempatan $=\frac{\text { Komisaris Independen }}{\text { Total Dewan Komisaris }} \times 100 \%$ & Rasio \\
\hline 6 & $\begin{array}{l}\text { Rasionalisasi } \\
\text { (CPA) }\end{array}$ & Rasionalisasi $=$ Pergantian Auditor & Dummy \\
\hline 7 & $\begin{array}{l}\text { Kompetensi } \\
\text { (DCHANGE) }\end{array}$ & Kompetensi $=$ Pergantian Direktur & Dummy \\
\hline 8 & $\begin{array}{l}\text { Arogansi } \\
\text { (CEOPIC) }\end{array}$ & Arogansi $=$ Jumlah foto $C E O$ & Nominal \\
\hline
\end{tabular}

Alat bantu analisis SPSS yang digunakan dalam menguji regresi linier berganda. Sebelum dilakukan pengujian regresi, peneliti juga menggunakan uji asumsi klasik sebagai syarat terpenuhinya uji regresi. uji normalitas, uji multikolonieritas, uji autokoreasi dan uji heteroskedastisitas adalah uji prasyarat yang peneliti gunakan sebelum menguji regresi linier berganda. Peneliti menggunakan regresi linier berganda dikarenakan variabel dependen pada penelitian ini dihitung menggunakan rasio dan varianel independennya lebih dari 2 variabel. Persamaan $M L=a+\beta_{1}$ ACHANGE $+\beta_{2}$ LEV $+\beta_{3}$ ROA $+\beta_{4}$ BDOUT $+\beta_{5} \mathrm{CPA}+\beta_{6} \mathrm{DCHANGE}+\beta_{7} \mathrm{CEOPIC}+\varepsilon$ adalah persamaan regresi linier berganda pada penelitian ini. Pengujian hipotesis menggunakan uji parsial (uji t) dengan alat bantu SPSS dan koefisien determinasi untuk mendeteksi prosentasi pengaruh variabel $\mathrm{X}$ terhadap variabel $\mathrm{Y}$. 


\section{HASIL PENELITIAN DAN PEMBAHASAN Statistik Deskriptif}

Statistik deskriptif data penelitian berupa jumlah sampel, nilai minimum, nilai maksimum, rata-rata dan standar deviasi. Tabel 2 berikut ini adalah tabel Statistik Deskriptif:

Tabel 2. Descriptive Statistics

\begin{tabular}{lcrrrr}
\hline & $\mathrm{N}$ & \multicolumn{1}{c}{ Minimum } & \multicolumn{1}{c}{ Maximum } & \multicolumn{1}{c}{ Mean } & \multicolumn{1}{c}{ Std. Deviation } \\
\hline Stabilitas Keuangan & 72 & -875076863.00 & 8101666318.00 & 177029011.5972 & 962346860.88197 \\
\hline Tekanan Eksternal & 72 & 465712.00 & 843509641.00 & 309541887.9722 & 212721385.24260 \\
\hline Target Keuangan & 72 & -219.00 & 2615.00 & 472.5025 & 561.72637 \\
\hline Kesempatan & 72 & 3.00 & 428571429.00 & 152569728.0556 & 172732069.61392 \\
\hline Pergantian Auditor & 72 & .00 & 1.00 & .1250 & .33304 \\
\hline Pergantian Direktur & 72 & .00 & 1.00 & .0556 & .23067 \\
\hline Gambar CEO & 72 & .00 & 22.00 & 9.4028 & 5.53264 \\
\hline Valid N (listwise) & 72 & & & & \\
\hline
\end{tabular}

Jumlah observasi ada 72. Nilai Mean pada stabilitas keuangan msebesar 177.029.011,5972 artinya perubahan aset perusahaan memiliki nilai yang baik. Nilai Minimum Gambar CEO adalah 0,00 dan Maksimumnya 22,00 dan Meannya 9,4028. Artinya gambar CEO pada observasi ini memiliki gambar CEO paling banyak 22 dan rata-rata gambar CEO dalam observasi sejumlah 9.

\section{Uji Normalitas}

Data penelitian yang baik adalah data yang berdistribusi normal. Untuk menguji data penelitian berdistribusi normal atau tidak pada penelitian ini, peneliti menggunakan uji normalitas. Data dikatakan normal apabila nilai probabilitas signifikansi One Sample Kolmogorov Smirnov Test $>0,05$, bisa pula menggunakan diagram plot dan histogram. Akan tetapi diagram plot dan histrogram memberikan asumsi yang berbeda, sehingga peneliti menggunakan nilai One Sample Kolmogorov Smirnov Test.

Tabel 3. Uji Normalitas One-Sample Kolmogorov-Smirnov Test

\begin{tabular}{llr}
\hline & & \multicolumn{2}{c}{$\begin{array}{c}\text { Unstandardized } \\
\text { Residual }\end{array}$} \\
\hline $\mathrm{N}$ & Mean & 72 \\
\hline Normal Parameters & a,b & .0000000 \\
\cline { 2 - 3 } & Std. Deviation & 54798065.19605 \\
& & 340 \\
\hline Most Extreme Differences & Absolute & .089 \\
\cline { 2 - 3 } & Positive & .089 \\
\cline { 2 - 3 } & Negative & -.080 \\
\hline Test Statistic & & .089 \\
\hline Asymp. Sig. (2-tailed) & & $.200^{\mathrm{c}, \mathrm{d}}$ \\
\hline
\end{tabular}

Kesimpulan dari tabel diatas adalah data peneliti berdistribusi normal. Hal ini dibuktikan dengan taraf signifikansi 0,200 yang berarti >0,05.

\section{Uji Multikolonieritas}

Multikolonieritas digunakan untuk mengetahui apakah terjadi hubungan variabel bebas dan variabel terikat. Model yang tidak mengandung atau tidak terjadi multikolonieritas adalah model yang baik. Untuk mengetahui model mengandung korelasi atau tidak dapat dilihat pada nilai Tolerance dan Variance Inflation Factor (VIF) pada tabel berikut ini: 
Tabel 4. Uji Multikolonieritas Coefficients $^{\mathrm{a}}$

\begin{tabular}{llrr}
\hline \multirow{2}{*}{ Model } & & \multicolumn{2}{c}{ Collinearity Statistics } \\
\cline { 3 - 4 } & & Tolerance & VIF \\
\hline \multirow{2}{*}{1} & Stabilitas Keuangan & .963 & 1.038 \\
\cline { 2 - 4 } & Tekanan Eksternal & .614 & 1.628 \\
\cline { 2 - 4 } & Target Keuangan & .705 & 1.419 \\
\cline { 2 - 4 } & Kesempatan & .881 & 1.135 \\
\cline { 2 - 4 } & Pergantian Auditor & .615 & 1.627 \\
\cline { 2 - 4 } & Pergantian Direktur & .569 & 1.759 \\
\cline { 2 - 4 } & Gambar CEO & .613 & 1.632 \\
\hline
\end{tabular}

a. Dependent Variable: Manajemen Laba

Nilai tolerence dari output di atas adalah $>0,1$ dan nilai VIF < artinya dalam model penelitian ini tidak terjadi multikolonieritas atau tidak terjadi kemiripan variabel sehingga tidak mengakibatkan korelasi yang sangat kuat.

\section{Uji Autokorelasi}

Model penelitian yang baik adalah yang tidak terjadi autokorelasi. Uji Autokorelasi adalah uji asumsi klasik yang digunakan untuk mendeteksi antar variabel penelitian variabel penelitian mempunyai korelasi waktu penelitian. Berikut ini adalah hasil uji autokorelasi.

Tabel 5. Uji Autokorelasi

Model Summaryb

\begin{tabular}{|c|c|c|c|c|c|}
\hline Model & $\mathrm{R}$ & R Square & $\begin{array}{l}\text { Adjusted R } \\
\text { Square }\end{array}$ & $\begin{array}{c}\text { Std. Error of the } \\
\text { Estimate }\end{array}$ & Durbin-Watson \\
\hline 1 & $.250^{\mathrm{a}}$ & .063 & .049 & 53628184.76778036 & 2.002 \\
\hline
\end{tabular}

a. Predictors: (Constant), Lag_e

b. Dependent Variable: Unstandardized Residual

Berdasarkan dari tabel diatas, dapat disimpulkan pada penelitian ini tidak terjadi autokorelasi. Hal ini dibuktikan dengan kriteria dari Uji Autokorelasi du $<\mathrm{dw}<4-$ du dan hasilnya adalah 1,8358 $<2,002$ $<2.1642$.

\section{Uji Heteroskedastisitas}

Dalam penelitian, model yang mengandung hereroskedastisitas harus dihindari. Apabila terjadi hereoskedastisitas model harus diobati. Uji heteroskedastisitas merupakan salah satu uji prasyarat uji regresi. Pada penelitian ini, peneliti menggunakan Uji Glejser dalam mendeteksi Uji Heteroskedastisitas.

Tabel 6. Uji Heteroskedastisitas Coefficients $^{a}$

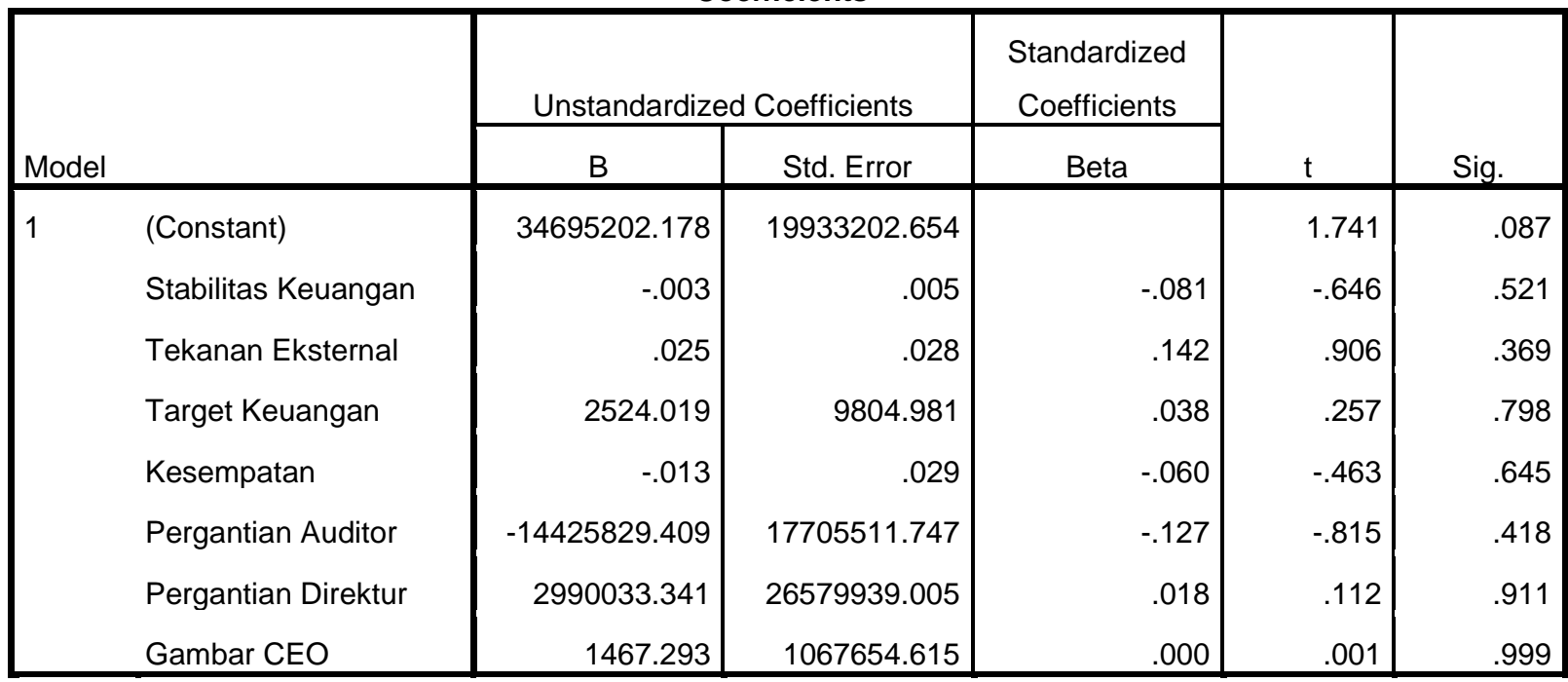

a. Dependent Variable: AbsUT 
Hasil output SPSS yang terbaca dalam tabel 6 menyatakan bahwa dalam model penelitian ini tidak terjadi uji heteroskedastisitas. Hal ini dibuktikan dari nilai signifikansi tiap variabel $>0,05$ yang tidak ada gejala heteroskedastisitas.

\section{Uji Hipotesis}

Hipotesis adalah jawaban sementara dari rumusan masalah. Dalam penelitian ini Uji t digunakan dalam mendeteksi hipotesis. Adapun hasilnya dapat dilihat pada tabel berikut ini:

\begin{tabular}{|c|c|c|c|c|c|c|}
\hline & & & $\begin{array}{l}\text { el 7. Uji t } \\
\text { ficients }\end{array}$ & & & \\
\hline & & Unstandardize & Coefficients & $\begin{array}{c}\text { Standardized } \\
\text { Coefficients }\end{array}$ & & \\
\hline Model & & $\mathrm{B}$ & Std. Error & Beta & $\mathrm{t}$ & Sig. \\
\hline 1 & (Constant) & 114654687.965 & 29532902.359 & & 3.882 & .000 \\
\hline & Stabilitas Keuangan & .005 & .007 & .079 & .716 & .477 \\
\hline & Tekanan Eksternal & -.134 & .041 & -.452 & -3.258 & .002 \\
\hline & Target Keuangan & 13375.011 & 14526.996 & .119 & .921 & .361 \\
\hline & Kesempatan & .014 & .042 & .038 & .329 & .743 \\
\hline & Pergantian Auditor & -12384684.121 & 26232370.117 & -.065 & -.472 & .638 \\
\hline & Pergantian Direktur & 14842608.499 & 39380663.358 & .054 & .377 & .707 \\
\hline & Gambar CEO & -1252154.737 & 1581830.078 & -.110 & -.792 & .432 \\
\hline
\end{tabular}

a. Dependent Variable: Manajemen Laba

Hasil dari taraf signifikansi :

- Variabel stabilitas keuangan menunjukkan angka statistik 0,477 yang artinya $>0,05$, sehingga dapat disimpulkan bahwa Variabel stabilitas keuangan tidak berpengaruh terhadap Manajemen Laba.

- $\quad$ Variabel Tekanan Eksternal menunjukkan angka statistik 0,002 yang artinya < 0,05, sehingga dapat disimpulkan bahwa Variabel Tekanan Eksternal berpengaruh terhadap Manajemen Laba.

- $\quad$ Variabel Target Keuangan menunjukkan angka statistik 0,361 yang artinya > 0,05, sehingga dapat disimpulkan bahwa Variabel Target Keuangan tidak berpengaruh terhadap Manajemen Laba.

- Variabel Kesempatan menunjukkan angka statistik 0,743 yang artinya > 0,05, sehingga dapat disimpulkan bahwa Variabel Kesempatan tidak berpengaruh terhadap Manajemen Laba.

- Variabel Pergantian Auditor menunjukkan angka statistik 0,638 yang artinya > 0,05, sehingga dapat disimpulkan bahwa Variabel Pergantian Auditor tidak berpengaruh terhadap Manajemen Laba.

- $\quad$ Variabel Pergantian Direktur menunjukkan angka statistik 0,707 yang artinya $>0,05$, sehingga dapat disimpulkan bahwa Variabel Pergantian Direktur tidak berpengaruh terhadap Manajemen Laba.

- Variabel Gambar CEO menunjukkan angka statistik 0,432 yang artinya > 0,05, sehingga dapat disimpulkan bahwa Variabel Gambar CEO tidak berpengaruh terhadap Manajemen Laba.

Berikut ini adalah Persamaan Regresi pada penelitian ini:

$$
\begin{aligned}
\text { Manajemen Laba }= & 114654687,965+0,005 \mathrm{ACHANGE}-0,134 \mathrm{LEV}+13375,011 \mathrm{ROA}+ \\
& 0,014 \mathrm{BDOUT}-12384684,121 \mathrm{CPA}+14842608,499 \mathrm{DCHANGE}- \\
& 1252154,737 \mathrm{CEOPIC}+\mathrm{e}
\end{aligned}
$$

\section{Koefisien Determinasi}

Koefisien determinasi digunakan untuk mengetahui berapa persen prosentase variabel stabilitas keuangan, tekanan eksternal, target keuangan, kesempatan pergantian auditor, pergantian direktur dan gambar CEO dalam mempengaruhi manajemen laba. 
Tabel 8. Koefisien Determinasi Model Summaryb

\begin{tabular}{lcccc}
\hline Model & $\mathrm{R}$ & $\mathrm{R}$ Square & $\begin{array}{c}\text { Adjusted } \mathrm{R} \\
\text { Square }\end{array}$ & \multicolumn{2}{c}{$\begin{array}{c}\text { Std. Error of the } \\
\text { Estimate }\end{array}$} \\
\hline 1 & $.495^{\mathrm{a}}$ & .245 & .162 & 57717088.07778 \\
\hline
\end{tabular}

a. Predictors: (Constant), Gambar CEO, Pergantian Auditor, Stabilitas

Keuangan, Target Keuangan, Kesempatan, Tekanan Eksternal, Pergantian Direktur

b. Dependent Variable: Manajemen Laba

Nilai Adjusted $R$ square pada tabel diatas sebesar 0,162. Artinya variabel stabilitas keuangan, tekanan eksternal, target keuangan, kesempatan, pergantian auditor, pergantian direktur dan gambar CEO sebesar $16,2 \%$ dapat mempengaruhi variabel manajemen laba dan sebesar $83,8 \%$ sisanya dipengaruhi oleh variabel lain diluar penelitian.

\section{Pengaruh Stabilitas Keuangan terhadap Pendeteksian Kecurangan Laporan Keuangan}

Stabilitas keuangan diproksikan dengan perubahan total aset. Hasil penelitian menunjukkan bahwa variabel stabilitas keuangan menunjukkan angka statistik 0,477 yang artinya $>0,05$, sehingga dapat disimpulkan bahwa variabel stabilitas keuangan tidak berpengaruh terhadap Manajemen Laba. Dapat disimpulkan bahwa stabilitas keuangan tidak dapat menjadi indikator dalam pendeteksian kecurangan laporan keuangan. Hasil penelitian ini sejalan dengan Rusmana dan Hendra (2019). Septriani dan Desi (2018) juga mentakan bahwa stabilitas keuangan tidak berpengaruh terhadap kecurangan laporan keuangan. Hidayah dan Galih (2019) juga menyatakan hal yang sama.

Hal ini menunjukkan bahwasannya perubahan total aset yang terjadi pada perusahaan manufaktur bukan merupakan indikator dalam kecurangan laporan keuangan. Perubahan total aset yang dimiliki perusahaan digunakan sebagai acuan perusahaan untuk mengetahui kekayaan yang dimiliki dan digunakan untuk menghitung kemampuan perusahaan dalam menyelesaikan kewajibannya.

\section{Pengaruh Tekanan Eksternal terhadap Pendeteksian Kecurangan Laporan Keuangan}

Variabel Tekanan Eksternal diproyeksikan dengan nilai rasio leverage. Hasil penelitian menunjukkan angka statistik 0,002 yang artinya $<0,05$, sehingga dapat disimpulkan bahwa Variabel Tekanan Eksternal berpengaruh terhadap Manajemen Laba. Hasil penelitian ini sejalan dengan penelitian Rusmana dan Hendra (2019) dan hasil penelitiannya Septriani dan Desi (2018). Khoirunnisa (2020) juga menyatakan bahwa tekanan eksternal berpengaruh terhadap Fraudulent Financial Reporting.

Tekanan eksternal adalah kondisi di mana suatu entitas mendapat tekanan dari pihak luar. Salah satu contoh tekanan eksternal yang terjadi di perusahaan adalah ketika sebuah perusahaan mencari sumber pendanaan untuk meningkatkan kinerja operasional dan non-operasional melalui pinjaman kepada kreditor.(Hidayah dan Galih, 2019). Entitas yang memiliki nilai rasio leverage tinggi maka perusahaan tersebut memungkinkan melakukan kecurangan laporan keuangan. Hal ini disebabkan perusahaan akan terus menerus mencari dana baik dari investor maupun kreditor, sehingga perusahaan memanipulasi laporan keuangan agar perusahaan dipercaya oleh kreditor dan investor.

\section{Pengaruh Target Keuangan terhadap Pendeteksian Kecurangan Laporan Keuangan}

Target keuangan pada penelitian ini menggunakan rasio ROA. Variabel Target Keuangan menunjukkan angka statistik 0,361 yang artinya $>0,05$, sehingga dapat disimpulkan bahwa Variabel Target Keuangan tidak berpengaruh terhadap Manajemen Laba. Hasil penelitian ini sejalan dengan penelitian Rusmana dan Hendra (2019), hasil penelitiannya Septriani dan Desi (2018) dan hasil penelitiannya Ratnasari dan Badingatus (2019).

Pencapaian moneter yang harus dipenuhi oleh seorang manajer dalam satu periode adalah definisi target keuangan dari Hidayah dan Galih (2019). Semakin tinggi nilai ROA yang dimiliki oleh perusahaan maka semakin tinggi pula keinginan perusahaan untuk meningkatkan nilai ROA dimasa yang akan datang. Sehingga ROA tidak dapat mempengaruhi kecurangan laporan keuangan. 


\section{Pengaruh Kesempatan terhadap Pendeteksian Kecurangan Laporan Keuangan}

Variabel Kesempatan menunjukkan angka statistik 0,743 yang artinya > 0,05, sehingga dapat disimpulkan bahwa Variabel Kesempatan tidak berpengaruh terhadap Manajemen Laba. Hasil penelitian ini sejalan dengan penelitian Rusmana dan Hendra (2019) dan hasil penelitiannya Septriani dan Desi (2018). Variabel kesempatan dilihat dari rasio jumlah komisaris independen dengan jumlah total dewan komisaris. Keberadaan dewan komisaris tidak dapat menjadi indikator perusahaan melakukan kecurangan laporan keuangan. Keberadaan dewan komisaris dalam perusahaan memiliki tugas memberikan nasihat kepada perusahaan agar perushaan dapat meningkatkan laba dan eksistensinya. Jumlah dewan komisaris bukan menjadi indikator dalam pendeteksian kecurangan laporan keuangan. Secara umum, dewan komisaris hanya datang ketika ada rapat umum pemegang saham sehingga kehadirannya tidak bepengaruh terhadap kecurangan laporan keuangan.

\section{Pengaruh Rasionalisasi terhadap Pendeteksian Kecurangan Laporan Keuangan}

Rasionalisasi dalam penelitian ini, diukur dengan pergantian auditor. Variabel Pergantian Auditor menunjukkan angka statistik 0,638 yang artinya > 0,05, sehingga dapat disimpulkan bahwa Variabel Pergantian Auditor tidak berpengaruh terhadap Manajemen Laba. Hal ini sejalan dengan penelitian Khoirunnisa (2020), Septiani dan Desi (2018), Ratnasari dan Badingatus (2019). Pergantian Auditor bukan menjadi indikator dalam melakukan kecurangan laporan keuangan. Dalam sampel penelitian menunjukkan bahwa perusahaan yang mengganti auditor hanya ada 12,5\%. Hal ini dikarenakan sesuai dengan aturan pemerintah bahwa setiap 4 tahun perusahaan harus menganti auditor agar kredibilitas auditor tetap terjaga. Selain itu pergantian auditor juga dilakukan atas dasar ada ketidakpuasan perusahaan terhadap auditor. Perusahaan mengganti auditor dikarenakan ingin meningkatakan kualitas laporan keuangan perusahaan yang akan dipublikasi sehingga dapat menarik investor untuk menanamkan saham di perusahaan.

\section{Pengaruh Kompetensi terhadap Pendeteksian Kecurangan Laporan Keuangan}

Kompetensi merupakan kemampuan seseorang dalam melakukan suau tugas dan tanggungjawab. Kompetensi apada penelitian ini diikur dengan pergantian direktur. Variabel Pergantian Direktur menunjukkan angka statistik 0,707 yang artinya > 0,05, sehingga dapat disimpulkan bahwa Variabel Pergantian Direktur tidak berpengaruh terhadap Manajemen Laba. Hal ini sejalan dengan penelitian Septiani dan Desi (2018), Ratnasari dan Badingatus (2019) dan Khoirunnisa (2020). Pergantian Direktur yang dilakukan oleh perusahaan bukanlah karena adanya indikasi kecurangan laporan keuangan, melainkan memilih direktur sesuai dengan kemampuan dan keahliannya, sehingga dapat memberikan manfaat bagi perusahaan.

\section{Pengaruh Arogansi terhadap Pendeteksian Kecurangan Laporan Keuangan}

Jumlah gambar CEO adalah jumlah penggambaran seorang CEO di perusahaan dengan menampilkan profil foto dan/atau informasi lain tentang track record CEO yang ditampilkan berulang kali dalam laporan tahunan perusahaan (Crowe, 2011). Variabel Aroganti pada penelitian ini diukur dengan jumlah gambar CEO. Hasil penelitian menunjukkan bahwa Variabel Gambar CEO menunjukkan angka statistik 0,432 yang artinya >0,05, sehingga dapat disimpulkan bahwa Variabel Gambar CEO tidak berpengaruh terhadap kecurangan laporan keuangan. Hal ini sejalan dengan penelitian Septiani dan Desi (2018), Ratnasari dan Badingatus (2019) dan Khoirunnisa (2020). Laporan Keuangan yang sudah dipublikasikan, rata-rata mempunyai gambar CEO di dalam laporan keuangan tersebut. Jumlah gambar CEO yang ada dalam laporan keuangan ternyata tidak bisa menjadi indikator dalam kecurangan laporan keuangan. Foto/gambar CEO yang ada dilaporan keuangan bagi perusahaan digunakan untuk mempublikasikan/memperkenalkan CEO kepada masyarakat. Selain itu, gambar CEO digunakan sebagai bentuk tanggungjawab siapa saja yang telah melakukan kegiatan diperusahaan dan juga memperkenalkan jajaran direksi kepada publik.

\section{SIMPULAN}

Stabilitas keuangan tidak berpengaruh terhadap pendeteksian kecurangan laporan keuangan. Tekanan eksternal berpengaruh terhadap pendeteksian kecurangan laporan keuangan. Target keuangan tidak berpengaruh terhadap pendeteksian kecurangan laporan keuangan. Kesempatan tidak berpengaruh 
terhadap pendeteksian kecurangan laporan keuangan. Rasionalisasi tidak berpengaruh terhadap pendeteksian kecurangan laporan keuangan. Kompetensi tidak berpengaruh terhadap pendeteksian kecurangan laporan keuangan. Arogansi tidak berpengaruh terhadap pendeteksian kecurangan laporan keuangan.

Peneliti selanjutnya hendaknya menambah observasi, hal ini disebabkan penelitian ini hanya menggunakan observasi perusahaan manufaktur, peneliti selanjutnya dapat menambah observasi perusahaan BUMN dan Perbankan. Peneliti selanjutnya juga dapat menambah rentang waktu penelitian, dan juga menggunakan metode lain dalam pengungkapan manajemen laba.

\section{REFERENSI}

Agoes, Sukrisno. (2018). Auditing Petunjuk Praktis Pemeriksaan Akuntan oleh Akuntan Publik. Jakarta: Salemba Empat.

Bawekes, Helda F. Aaron M.A Simanjuntak dan Sylvia Christina Daat. (2018). Pengujian Teori Fraud Pentagon terhadap Fraudulent Financial Reporting. Jurnal Akuntansi \& Keuangan Daerah Volume 13, Nomor 1, Mei 2018: 114-134.

Crowe, H. 2011. Putting the Freud in Fraud: Why the Fraud Triangle Is No Longer Enough. IN Horwarth.

Danuta, Krisnhoe Sukma. (2017). Crowe's Fraud Pentagon Theory dalam Pencegahan Fraud pada Proses Pengadaan melalui E-eprocurement. Jurnal Kajian Akuntansi, Vol 1, (2), 161-171

Hidayah, Erna. Galih Devi Saptarini. (2019). Pentagon Fraud Analysis in Detecting Potential Financial Statement Fraud of Banking Companies in Indonesia. Proceeding of The 3rd International Conference on Accounting, Business \& Economics (UII-ICABE 2019).

Khoirunnisa, Awaliyatu. Anita Rahmawati. Yasin. (2020). Fraud Pentagon Theory dalam Mendeteksi Fraudulent Financial Reporting Pada Perusahaan yang Terdaftar di Jakarta Islamic Index 70 (JII 70) Tahun 2018. Bisnis: Jurnal Bisnis dan Manajemen Islam. Vol 8, No 1.

Marks, J. (2012). The mind behind the fraudsters crime: Key behavioral and environmental elements. In ACFE Global Fraud Conference. Association of Certified Fraud Examiners.

Ratnasari, Estu. Badingatus Solikhah. (2019). Analisis Kecurangan Laporan Keuangan: Pendekatan Fraud Pentagon Theory. Gorontalo Accounting Journal. Vol.2 No. 2

Rusmana, Oman. Hendra Tanjung. (2019). Identifikasi Kecurangan Laporan Keuangan dengan Fraud Pentagon Studi Empiris BUMN Terdaftar di Bursa Efek Indonesia. Jurnal Ekonomi, Bisnis dan Akuntansi (JEBA). Vol 2 No 4.

Sasongko, Noer. Sangrah Fitriana Wijayantika. (2019). Faktor Resiko Fraud terhadap Pelaksanaan Fraudulent Financial Reporting (Berdasarkan Pendekatan Crown's Fraud Pentagon Theory). Jurnal Riset Akuntansi dan Keuangan Indonesia. Vol. 4. No.1

Septriani, Yossi. Desi Handayani. (2018). Mendeteksi Kecurangan Laporan Keuangan dengan Analisis Fraud Pentagon. Jurnal Akuntansi, Keuangan dan Bisnis. Vol 11, No 1, 11-23

Skousen, C. J., Smith, K. R., \& Wright, C. J. (2009). Detecting and predicting financial statement fraud: Theeffectiveness of the fraud triangle and SAS No. 99. Advances in Financial Economics: Corporate Governance and Performance, 13, 53-81.

Wolfe, D. T., \& Hermanson, D. R. (2004). The fraud diamond: Considering the four elements of fraud. CPA Journal, (December 2014), 38-42. 